\title{
Low back pain in women before and after menopause
}

\author{
Mateusz Kozinoga ${ }^{1,2}$, Marian Majchrzycki ${ }^{3}$, Sylwia Piotrowska ${ }^{4}$ \\ ${ }^{1}$ Spine Disorder Unit, Department of Pediatric Orthopedics, Poznan University of Medical Sciences, Poznan, Poland \\ ${ }^{2}$ Rehasport Clinic Poznan, Poland \\ ${ }^{3}$ Department of Rheumatology and Rehabilitation, Poznan University of Medical Sciences, Poznan, Poland \\ ${ }^{4}$ Department of Physiology, Poznan University of Medical Sciences, Poznan, Poland
}

\begin{abstract}
Low back pain is a massive problem in modern population, both in social and economic terms. It affects large numbers of women, especially those aged 45-60. Going through a perimenopausal period is associated with many symptoms, including low back pain.

This paper is a review of published research on the association between the perimenopausal age and low back pain. PubMed databases were investigated. After the search was narrowed to "menopausal status, back pain", 35 studies were found. Seven studies, which suited our area of research best, were thoroughly analyzed. All studies show increased pain when women enter this period of their life. There is no agreement among researchers regarding which stage of menopause is the most burdensome.

Examples of possible treatments and physiotherapeutic methods targeting low back pain are also presented. Physiotherapeutic procedures used to treat low back pain include exercises in safe positions, balance exercises, manual therapy, massage and physical measures.
\end{abstract}

Key words: menopause, low back pain.

\section{Introduction}

As their life expectancy increases, contemporary women live a third of their life in menopause [1]. Chronic pain is more prevalent in women than in men, and it increases with age [2-4]. According to Whelan et al., even $80 \%$ of women suffer from various symptoms (including pain) in the perimenopausal period (which is usually defined as the age range of 45-55) [5].

Going from a premenopausal period to a postmenopausal one is a result of slower production of female hormones by ovaries. This process is gradual and spread over time, and a natural part of aging. Numerous symptoms associated with the perimenopausal period have been identified. Physical ones can include spine and joint pain, hot flashes, night sweats, chronic tiredness; psychological symptoms can include irritation and anxiety, mood swings, depression and sleep disorders. The analyzed studies showed an association between the menopausal period and depression, hot flashes and sleep disorders but little attention was paid to pain (in spine and peripheral joints) as an equally prevalent symptom associated with this period of life [6].

This review focuses on the association between the perimenopausal and post-menopausal periods of life and low back pain (LBP). Additionally, it describes physiotherapeutic procedures used to treat low back pain.

Spine pain, especially in the lumbar region, is a serious health issue in the modern world. At some point in life, $36.4 \%$ to $58 \%$ of people in European countries and the United States experience LBP $[7,8]$. This poses a great medical and socio-economic challenge to such extent that some researchers call it a lifestyle disease. It is the main cause of absence in the workplace, and the second cause of visiting primary health care professionals. Spine pain has negative psychological consequences as it impairs daily functioning of the affected person. It also poses a serious socio-economic problem - it is costly due to disability-related absence in the workplace [9].

The purpose of the paper is to review available studies on perimenopausal women with LBP. This review can shed more light on the issue of pain in women who undergo menopause.

\section{Back pain in women in the perimenopausal period}

PubMed databases were investigated. After the search was narrowed to "menopausal status, back pain", 35 studies were found. 
The selected studies were analyzed to verify whether they described the perimenopausal period of life, correlated back pain and menopausal status, divided the study group into sub-groups depending on the menopausal status (not all studies did).

Twenty-eight papers were excluded due to lack of information about back pain and menopausal status. Seven studies, which suited our area of research best, were thoroughly analyzed.

Most studies [1, 10-12] divided women into five groups:

1. Premenopausal women who had had a regular period in the past three months.

2. Early perimenopausal women who had an irregular period in the past three months.

3. Late perimenopausal women who had menstruated irregularly in the last 12 months but not in the last 3 months.

4. Postmenopausal women who had not menstruated in the last 12 months.

A separate group of women who have hormone replacement therapy.

All analyzed studies showed that women who are experiencing or experienced menopause suffered from increased joint and spine pain.

According to Dugan et al. [10], $61 \%$ of women in the study group of 2218 reported lumbar spine pain. Back pain experienced at least once in two weeks prior to the study was reported by $56 \%$ of 294 women in group 1 (premenopausal), $65 \%$ of 856 women in group 2 (early perimenopausal), $59 \%$ of 137 women in group 3 (late perimenopausal) and $61 \%$ of 152 women in group 4 (postmenopausal). Additionally, an association between increased BMI and increased pain was observed, which probably is a result of increased mechanical loading of the spine. Mitchell and Woods [12] divided their study subjects into similar groups. In group 1 (late reproductive stage), of 196 women, $81.6 \%$ reported pain; in group 2 (early transition stage), of 171 women, $77.8 \%$ reported pain; in group 3 (late transition stage), of 106 women, $83 \%$ reported pain; in group 4 (early postmenopause), of 67 women, $80.6 \%$ reported pain.

A long-term study by Szoeke et al. [11] established that in the period of 8 years, the number of women suffering from back pain grew from $44 \%$ to $59 \%$. Most women who took part in this study went from the premenopausal to postmenopausal stage during the study. The authors of the study also noticed a direct association between increased BMI and increased spine pain.

A study by Poomalar and Bupathy [1] on the Indian female population divided 500 participants into 3 subgroups (perimenopausal, early postmenopausal and late postmenopausal). A low back pain incidence was as follows: $80 \%(n=135), 76 \%(n=133)$, and $79 \%(n=232)$, respectively.
A Japanese study by Manabe [13] of 2244 women (group 1: 25-44 years, $n=719$; group 2: $45-64$ years, $n=1,153$; group 3: over 65 years, $n=372$ ) showed lumbar spine pain in $21 \%, 34 \%$ and $37 \%$ of study participants, respectively. A study by Sievert [14] on the Mexican female population is yet another paper showing the risk of developing low back pain in women going through a perimenopausal period of life.

A three-year study by Brennan Braden et al. [15] examined 67,963 postmenopausal women aged 50-79 with chronic pain (low back pain, neck pain, headache, joint pain or stiffness) and established that increased BMI ( $\geq 30$ ) was associated with the worsening of pain. What is interesting is that when an opioid-using group was compared to the group not using opioids, it turned out that the former tended to have worse pain scores (mean 41 vs. 72.6), worse physical functioning ( 56.8 vs. 80.6 ), slightly higher BMI (29.5 vs. 27.3 ), were more likely to be disabled (13.5\% vs. $1.9 \%$ ) and were more likely to be diagnosed with depression $(20.5 \%$ vs. $11.1 \%)$.

There are disagreements in the literature about the relationship between $\mathrm{BMI}$ and low back pain. A study of Australian community-dwelling women from 2010 reported a direct association between high BMI and both high low back pain intensity and disability [16]. On the other hand, a 2010 study by Park et al. [17], in which 78 Korean women hospitalized due to spine pain were observed, took a look at a relationship between BMI, bone mineral density, age and the stage of postmenopause. The results showed no association between BMI and the incidence of back pain. This could be due to a small number of studied cases with BMI higher than 30 (3 women out of 78). The study also concluded that compared to women with normal bone mineral density, women with lower bone mineral density were significantly older $(p=0.003)$ and had been postmenopausal for a longer time $(p=0.031)$.

All these studies seem to unanimously suggest an increased incidence of low back pain in perimenopausal women comparing to other age groups. Table I shows all of the discussed studies. None of them contained any information about the treatment of pain which would take into consideration perimenopauserelated factors (the risk of osteoporosis, hormonal imbalance). These topics are legitimate topics for further research.

On the other hand, Holte [18] concludes that the menopausal period of life is not always associated with negative symptoms. Norwegian women he studied reported a lower incidence of headaches during menopause. Moreover, sleep disorders could be a factor in spine pain. Resting can influence muscle tension and tiredness, as a result reducing the pain [19]. We have not found any studies which would examine this issue in depth. 
Tab. I. Summary of reviewed literature

\begin{tabular}{|c|c|c|c|c|}
\hline Study & $\begin{array}{c}\text { Number } \\
\text { of participants }\end{array}$ & $\begin{array}{l}\text { Group specific therapy/ } \\
\text { Study groups }\end{array}$ & $\begin{array}{l}\text { Comparison between } \\
\text { groups }\end{array}$ & Outcomes, conclusions \\
\hline $\begin{array}{l}\text { Dugan et al. } \\
{[10]}\end{array}$ & 2218 women & $\begin{array}{l}\text { Group 1: Premenopausal } \\
\text { (294 women) } \\
\text { Group 2: Early perimenopausal } \\
\text { (856 women) } \\
\text { Group 3: Late perimenopausal } \\
\text { (137 women) } \\
\text { Group 4: Postmenopausal } \\
\text { (152 women) }\end{array}$ & $\begin{array}{l}\text { Premenopausal women were } \\
\text { least affected by symptoms. } \\
\text { The biggest increase in pain } \\
\text { symptoms was observed } \\
\text { in early perimenopausal } \\
\text { women. }\end{array}$ & $\begin{array}{l}\text { Aches and pain are significantly } \\
\text { and independently related with } \\
\text { the postmenopausal status. }\end{array}$ \\
\hline $\begin{array}{l}\text { Mitchell et al. } \\
{[12]}\end{array}$ & 540 women & $\begin{array}{l}\text { Group 1: Late reproductive } \\
\text { stage (196 women) } \\
\text { Group 2: Early transition stage } \\
\text { (171 women) } \\
\text { Group 3: Late transition stage } \\
\text { (106 women) } \\
\text { Group 4: Early postmenopause } \\
\text { (67 women) }\end{array}$ & $\begin{array}{l}\text { The most severe pain symp- } \\
\text { toms in the low back were } \\
\text { observed in groups } 3 \text { and } 1 .\end{array}$ & $\begin{array}{l}\text { Back pain increased in severity } \\
\text { as women progressed through } \\
\text { the menopausal transition } \\
\text { stages. }\end{array}$ \\
\hline $\begin{array}{l}\text { Szoeke et al. } \\
{[11]}\end{array}$ & 438 women & $\begin{array}{l}\text { Australian-born women, aged } \\
45-55 \text { years and menstruating } \\
\text { at baseline }\end{array}$ & & $\begin{array}{l}\text { In the period of } 8 \text { years, the } \\
\text { number of women suffering } \\
\text { from back pain grew from } 44 \% \\
\text { to } 59 \% \text {. A positive association } \\
\text { between increased BMI and in- } \\
\text { creased spine pain was observed. }\end{array}$ \\
\hline $\begin{array}{l}\text { Poomalar et al. } \\
\text { [1] }\end{array}$ & 500 women & $\begin{array}{l}\text { Group 1: In menopause transi- } \\
\text { tion (135 women) } \\
\text { Group 2: Early post menopause } \\
\text { (133 women) } \\
\text { Group 3: Late post menopause } \\
\text { (232 women) }\end{array}$ & $\begin{array}{l}\text { The highest incidence of } \\
\text { low back pain was observed } \\
\text { in the menopause transi- } \\
\text { tion group. The smallest } \\
\text { incidence rate, on the other } \\
\text { hand, was observed in the } \\
\text { early postmenopausal group. }\end{array}$ & $\begin{array}{l}\text { The menopause-related symp- } \\
\text { toms have a negative effect } \\
\text { on the quality of life of the } \\
\text { perimenopausal and postmeno- } \\
\text { pausal women. }\end{array}$ \\
\hline $\begin{array}{l}\text { Manabe et } \\
\text { al. [13] }\end{array}$ & 2244 women & $\begin{array}{l}\text { Group 1: Younger women, } \\
\text { 25-44 years }(n=719) \\
\text { Group 2: Middle-aged women, } \\
\text { 45-64 years }(n=1153) \\
\text { Group 3: Older women, } \\
\text { over } 65 \text { years }(n=372)\end{array}$ & $\begin{array}{l}\text { The spine pain incidence in- } \\
\text { creased with age, the largest } \\
\text { increase observed in group } 3 .\end{array}$ & $\begin{array}{l}\text { It can be assumed that there are } \\
\text { some differences in the primary } \\
\text { factors causing LBP between } \\
\text { the middle and the upper age } \\
\text { groups, with changes in the } \\
\text { condition of the lumbar spine } \\
\text { occurring gradually. }\end{array}$ \\
\hline $\begin{array}{l}\text { Brennan } \\
\text { Braden et al. } \\
{[15]}\end{array}$ & 67963 women & $\begin{array}{l}\text { Postmenopausal women aged } \\
50-79 \text { with chronic pain. }\end{array}$ & & $\begin{array}{l}\text { Increased } \mathrm{BMI}(\geq 30) \text { is associ- } \\
\text { ated with the worsening of pain. }\end{array}$ \\
\hline $\begin{array}{l}\text { Park et al. } \\
{[17]}\end{array}$ & 78 women & $\begin{array}{l}\text { Korean women hospitalized } \\
\text { due to spine pain. }\end{array}$ & & $\begin{array}{l}\text { No association between BMI and } \\
\text { the incidence of back pain. }\end{array}$ \\
\hline
\end{tabular}

\section{Treating low back pain in perimenopausal women}

Physiotherapeutic procedures used to treat low back pain include exercises, manual therapy, massage and physical measures. Pharmacology is also used (e.g. non-steroidal anti-inflammatory drugs) [20, 21].

According to Mishra et al. [22], the exercise program for postmenopausal women should include endurance (aerobic) exercises, strength exercises and balance exercises. Out of these, aerobics, weight bearing, and resistance exercises are effective at increasing the bone mineral density of the spine in postmenopausal women [23]. This is an extremely desirable effect considering the fact that bone mineral density tends to diminish at this stage of woman's life [24].
A meta-analysis by Hayden et al. [25] reviewed available research on exercise therapy for low back pain and concluded that the therapy is effective at slightly decreasing pain. However, it should be noted that the therapy was defined as "a series of specific movements with the aim of training or developing the body by a routine practice or as physical training to promote good physical health" [26]. This suggests a non-specific character of exercises in the treatment of lumbar spine pain. Nevertheless, recommending general physical exercises is beneficial because they undoubtedly promote weight loss, which is important in perimenopausal women who tend to be less physically active [24]. Moreover, Hayden et al. also concluded that the most effective exercise therapy strategy for chronic LBP was supervised and individually-tailored, high-dose stretch- 
ing and muscle strengthening exercise programs with home practice [25].

The American Pain Society and American College of Physicians stated that there is good evidence that specific physical exercises recommended by a physiotherapist have a moderate positive effect in low back pain. These organizations also pointed out that there is no good evidence for physical therapies (transcutaneous electrical nerve stimulation, ultrasounds) for low back pain and so they do not recommend their use [27].

Study by Cherkin et al. [28] compared the effects of physical therapy, chiropractic manipulation and provision of an educational booklet on low back pain. It concluded that physical therapy and chiropractic manipulation were similarly effective in terms of symptoms, functioning, satisfaction with care, disability, recurrences of back pain, and subsequent visits for back pain. There was no significant difference between a chiropractor or a physical therapist with regard to the length of the therapy, which lasted for about 2.5 hours.

Meade et al. [29] also points out to the benefits of manual therapy for low back pain.

A 2010 report by Bronfort et al. on the scientific evidence for manual treatment of pain (including low back pain) in Great Britain concluded that spinal manipulation and mobilization are effective in adults for acute, subacute, and chronic low back pain. It was also noted that as an alternative technique, massage is effective in adults for chronic low back [30].

Suggested specific physiotherapeutic procedures for low back pain for perimenopausal women:

- exercises in safe positions (with a minimal risk of worsening the pain): supine position - exercises strengthening the floor of the pelvis, the transversus abdominis and multifidus muscles, as they are the most important stabilizers of the lower parts of the spine,

- balance exercises,

- manual therapy.

\section{Conclusions}

The perimenopausal stage of life is associated with an increased incidence of low back pain. Increased BMI $(\geq 30)$ is one of the factors increasing the prevalence of pain. Suggested forms of treatment include physiotherapeutic procedures such as physical exercises, massage, and manual therapy. Further studies are necessary in the area of treatment of pain and association between insomnia and low back pain.

\section{Disclosure}

Authors report no conflict of interest.

\section{References}

1. Poomalar GK, Bupathy A. The quality of life during and after menopause among rural women. J Clin Diagn Res 2013; 7: 135-139.

2. Branden JB, Zhang L, Fn MY, et al. Mental health service use by older adults: the role of chronic pain. Am J Geriatr Psych 2008; 16: 156-167.

3. Stang PE, Brandenburg NA, Lane MC, et al. Mental and physical comorbid conditions and days in role among person with arthritis. Psychosom Med 2006; 68: 152-158.

4. Von Korff M, Crane P, Lane M, et al. Chronic spinal pain and physicalmental comorbidity in the United States: results from the national comorbidity survey replication. Pain 2005; 113: 331-339.

5. Whelan TJ, Goss PE, Ingle JN, et al. Assessment of quality of life in MA. 17: a randomized, placebo controlled trial of letrozole after 5 years of tamoxifen in postmenopausal women. J Clin Oncol 2005; 23: 6931-6940.

6. Cray L, Mitchell E, Woods N. Symptom clusters during the late menopausal transition stage: observations from the Seattle Midlife Women's Health Study. Menopause 2010; 17: 972-977.

7. Palmer K, Walsh K, Bendall $\mathrm{H}$, et al. Back pain in Britain: comparison of two prevalence surveys at an interval of 10 years. BMJ 2000; 320: 1577-1578.

8. Van Tulder MW, Koes BW, Bouter LM. A cost-of-illness study of back pain in the Netherlands. Pain 1995; 62: 233-240.

9. Chaitow L, Fritz S. A Massage Therapist's Guide to Lower Back \& Pelvic Pain. Elsevier Churchill, Livingstone 2007.

10. Dugan SA, Powell LH, Kravitz HM, et al. Musculoskeletal pain and menopausal status. Clin J Pain 2006; 22: 325-331.

11. Szoeke CE, Cicuttini FM, Guthrie JR, Dennerstein L. The relationship of reports of aches and joint pains to the menopausal transition: a longitudinal study. Climacteric 2008; 11: 55-62.

12. Mitchell ES, Woods NF. Pain symptoms during the menopausal transition and early postmenopause. Climacteric 2010; 13: 467-478.

13. Manabe T, Takasugi SI, Iwamoto Y. Positive relationship between bone mineral density and low back pain in middle-aged women. Eur Spine J 2003; 12: 596-601.

14. Sievert LL, Goode-Null SK. Musculoskeletal pain among women of menopausal age in Puebla, Mexico. Journal of Cross-Cultural Gerontology 2005; 20: 127-140.

15. Brennan Braden J, Young A, Sullivan MD, et al. Predictors of change in pain and physical functioning among post-menopausal women with recurrent pain conditions in the Women's Health Initiative Observational Cohort. Pain 2012; 13: 64-72.

16. Urquhart DM, Bell R, Cicuttini FM, et al. Low back pain and disability in community-based women: prevalence and associated factors. Menopause 2009; 16: 24-29.

17. Park JJ, Shin J, Youn Y, et al. Bone mineral density, body mass index, postmenopausal period and outcomes of low back pain treatment in Korean postmenopausal women. Eur Spine J 2010; 19: 1942-1947.

18. Holte A. Influences of natural menopause on health complaints: a prospective study of healthy Norwegian women. Maturitas 1992; 14: 127-141.

19. Ohayon M. Severe hot flashes are associated with chronic insomnia. Arch Intern Med 2006; 166: 1262-1268.

20. Chou R, Qaseem A, Snow V, et al. Diagnosis and treatment of low back pain: a joint clinical practice guideline from the American College of Physicians and the American Pain Society. Ann Intern Med 2007; 15 : 478-491.

21. Saper RB, Sherman KJ, Delitto A, et al. Yoga vs. physical therapy vs. education for chronic low back pain in predominantly minority populations: study protocol for a randomized controlled trial. Trials 2014; 15: 67.

22. Mishra N, Mishra VN, Devanshi. Exercise beyond menopause: Dos and Don'ts. J Midlife Health 2011; 2: 51-56.

23. Li WC, Chen YC, Yang RS, Tsauo JY. Effects of exercise programme on quality of life in osteoporotic and osteopenic postmenopausal women: a systemic review and meta-analysis. Clin Rehabil 2009; 23: 888-896.

24. Kim KZ, Shin A, Lee J, et al. The beneficial effect of leisure-time physical activity on bone mineral density in pre- and postmenopausal women. Calcified Tissue International 2012; 91: 178-185. 
25. Hayden J, Van Tulder MW, Malmivaara A, Koes BW. Exercise therapy for treatment of non-specific low back pain. Ann Intern Med 2005; 142 765-775.

26. Abenhaim L, Rossignol M, Valat JP, et al. The role of activity in the therapeutic management of back pain. Report of the International Paris Task Force on Back Pain. Spine 2000; 25: 1-33.

27. Chou R, Huffman LH. Nonpharmacologic therapies for acute and chronic low back pain: a review of the evidence for an American Pain Society/ American College of Physicians clinical practice guideline. Ann Intern Med 2007; 147: 492-504.
28. Cherkin DC, Deyo RA, Battié B, et al. Comparison of physical therapy, chiropractic manipulation, and provision of an educational booklet for the treatment of patients with low back pain. N Engl J Med 1998; 339: 1021-1029.

29. Meade TW, Dyer S, Browne W, Frank AO. Randomised comparison of chiropractic and hospital outpatient management for low back pain: results from extended follow up. BMJ 1995; 311: 349-351.

30. Bronfort G, Haas M, Evans R, et al. Effectiveness of manual therapies: the UK evidence report. Chiropractic \& Osteopathy 2010; 18: 3. 